\title{
Evaluation of $\mathrm{BC} 1$ and $\mathrm{BC} 2$ from the crossing Erianthus arundinaceus with Saccharum for resistance to sugarcane smut caused by Sporisorium scitamineum
}

\author{
Wan-Kuan Shen', Hai-Hua Deng'2, Qi-Wei Li², Zhan-Duan Yang² \& Zi-De Jiang ${ }^{3}$ \\ ${ }^{1}$ College of Agronomy, South China Agricultural University/Scientific Observing and Experimental Station of Crop \\ Cultivation in South China, Ministry of Agriculture, 510642, Guangdong, Guangzhou, China; ${ }^{2}$ Guangzhou Sugarcane \\ Industry Research Institute /Guangdong Key Laboratory of Sugarcane Improvement and Biorefinery, 510316, Guangdong, \\ Guangzhou, China; ${ }^{3}$ Department of Plant Pathology, South China Agricultural University/Guangdong Key Laboratory of \\ Microbial Signals and Disease Control, 510642, Guangdong, Guangzhou, China
}

Author for correspondence: Zide Jiang, e-mail: wkshen69@126.com

\begin{abstract}
Sugarcane smut disease caused by the fungus Sporisorium scitamineum is one of the important fungal diseases affecting sugarcane yield and sucrose content around the world. Cultivar resistance is the most appropriate control method for this disease. In this study, 37 $\mathrm{BC}_{1}$ lines chosen from the crossing YC96-40 $\left(\mathrm{F}_{1}\right.$ of Erianthus arundinaceus) $\times$ CP84-1198 (commercial sugarcane cultivar) and $42 \mathrm{BC}_{2}$ lines chosen from the crossing YCE01-116 $\left(\mathrm{BC}_{1}\right.$ of E. arundinaceus) $\times$ Neijiang57-416 (commercial sugarcane cultivar) were evaluated for smut resistance using artificial inoculation. The results showed that of 79 tested $\mathrm{BC}_{1}$ and $\mathrm{BC}_{2}$ lines of E. arundinaceus, 10 (12.7\%) were highly to moderately resistant to smut. $\mathrm{BC}_{1}$ of $E$. arundinaceus had more resistant lines than $\mathrm{BC}_{2}$ of $E$. arundinaceus. Of the 37 tested $\mathrm{BC}_{1}$ lines of $E$. arundinaceus, seven $(18.9 \%)$ were highly to moderately resistant, while three $(7.1 \%)$ of the 42 tested $\mathrm{BC}_{2}$ lines of E. arundinaceus were highly to moderately resistant to smut. The resistant lines identified in this study could be used as sources of smut resistance in sugarcane breeding programs.
\end{abstract}

Key words: Erianthus arundinaceus, Saccharum officinarum, Sporisorium scitamineum, backcross progenies, evaluation of resistance.

\section{INTRODUCTION}

Sugarcane (Saccharum hybrid species) is an important economic crop for sugar and ethanol production. Mainland China is currently the third largest producer of sugarcane in the world, following Brazil and India. Southern China, including Guangxi Zhuang autonomous region, Yunnan and Guangdong Provinces, is the major sugarcaneproducing region in mainland China (Chen \& Yuan, 2010). Sugarcane smut caused by the fungus Sporisorium scitamineum, formerly called Ustilago scitaminea (Stoll et al., 2003), is an important disease worldwide (Comstock, 2000). It was reported for the first time in the world in 1877 when it was found in Natal, South Africa (McMartin, 1945), and numerous outbreaks were noted in Africa and Asia in the following decades. Smut remained confined to the Eastern hemisphere until it was found in Argentina in 1940 (Comstock, 2000). In China, smut was found in 1932 in Guangzhou for the first time (Antoine, 1961; Presley, 1978). During the past 20 years, smut has developed into a major disease and caused serious yield loss in sugarcane production in mainland China (Que et al., 2012 ; Shen et al., 2013).

The most efficient and economic method for disease control, including sugarcane smut, is the use of resistant cultivars (Wada, 2003; Shen et al., 2014). However, the development of resistant sugarcane cultivars requires elite sources of resistance to smut. Modern sugarcane cultivars are derived from a relatively few interspecific hybrids between Saccharum officinarum L. and S. spontaneum L., resulting in a narrow germplasm base (Berding \& Roach, 1987). To increase this restricted genetic base, breeders have been interested in the introgression of genes from wild species.

Erianthus arundinaceus is an important closely related wild species of $S$. officinarum. This species has great potential as a germplasm source for modifying the ratooning ability, vigour, tolerance to environmental stresses, and disease resistance of sugarcane (George et al., 2000; Fukuhara et al., 2013). E. arundinaceus was first hybridized with sugarcane in 1885 (Deng et al., 2004). However, further progress was not made until the 1990s, because of the sterility of hybrids and the difficulty in identifying genuine progenies (Shen, 2002). In recent years, great progress has been made in the use of $E$. arundinaceus, and some promising $\mathrm{BC}_{1}$ and $\mathrm{BC}_{2}$ lines have been obtained from crossing E. arundinaceus with Saccharum (Deng et al., 2004). Several studies on physiological and biochemical characteristics or chromosome transmission in backcross 
progenies of $E$. arundinaceus have been conducted (Chen et al., 2006; Deng et al., 2007; Deng et al., 2009). However, there have been no reports on the assessment of $\mathrm{BC}_{1}$ and $\mathrm{BC}_{2}$ of $E$. arundinaceus for resistance to sugarcane smut. The objective of this study was to evaluate smut resistance in $\mathrm{BC}_{1}$ and $\mathrm{BC}_{2}$ lines of E. arundinaceus.

\section{MATERIALS AND METHODS}

\section{Materials and experimental site}

Seventy-ninebackcross progenies of E. arundinaceus, including $37 \mathrm{BC}_{1}$ lines and $42 \mathrm{BC}_{2}$ lines, and their parents, YC96-40 ( $\mathrm{F}_{1}$ of E. arundinaceus), CP84-1198 (commercial sugarcane cultivar), YCE01-116 ( $\mathrm{BC}_{1}$ of $E$. arundinaceus) and Neijiang57-416 (commercial sugarcane cultivar), were kindly provided by Hainan Sugarcane Hybridization Station, Guangzhou Sugarcane Industry Research Institute, Guangzhou, China. Seventy-nine $\mathrm{BC}_{1}$ and $\mathrm{BC}_{2}$ lines of E. arundinaceus, YC96-40 and YCE01-116 have been identified as true hybrids of $E$. arundinaceus by molecular approaches (He et al., 2008). This study was carried out in June of 2008 at Guangzhou Sugarcane Industry Research Institute, China.

\section{Preparation of planting sets}

Sugarcane stalks from a 7-month-old plantation were cut and the leaves dettached to expose the buds. These were then cut into one-budded setts ready for inoculation.

\section{Inoculation and planting of prepared planting sets}

For screening resistance in the field, teliospores of $S$. scitamineum were collected from mature unopened sori produced on canes in field at Zhanjiang sugarcane production areas, Guangdong Province, China. Spore germination was determined under a compound microscope (Olympus, Model BH-2) at $100 \times$ using a micro-counter as described by Bhuiyan et al. (2012). Two gram smut spores were mixed with one liter of distilled water as per standard screening practices (Shen \& Deng, 2011). The spore suspension is prepared in a 50 liter tank giving a concentration of approximately 4-5 million spores per milliliter. One-budded sets of the tested $\mathrm{BC}_{1}, \mathrm{BC}_{2}$ lines of $E$. arundinaceus and their parents were dipped into smut spore suspension for $30 \mathrm{~min}$ as described by Shen and Deng (2011). The inoculated sets were then incubated in wet jute gunny bags overnight and planted in plastic buckets $(35 \mathrm{~cm}$ diameter, $30 \mathrm{~cm}$ depth) filled with a steam-sterilized mixture of soil and organic matter $(3: 1 \mathrm{v} / \mathrm{v})$. A total of 30 plants of each test material were treated according to a completely randomized experimental design including three replicates of individual bucket containing 10 plants. Plants were grown in greenhouse at $28-30^{\circ} \mathrm{C}$.

\section{Investigation of incidence and resistance classification}

Approximately 4-5 weeks after inoculation, surveys of disease incidence were initiated and carried out every 15 days until the disease incidence was stable (six months). The date of inoculation, number of total stools, number of diseased stools were recorded. Disease reactions of the tested materials for $S$. scitamineum were rated on a scale from 1 to 9 based on the percentage of diseased stools (Shen et al., 2014), where 0-3\% was scored as grade 1 (highly resistant), $4-6 \%$ as grade 2 (resistant), $7-9 \%$ as grade 3 (resistant), $10-12 \%$ as grade 4 (moderately resistant), $13-$ $25 \%$ as grade 5 (moderately susceptible), $26-35 \%$ as grade 6 (susceptible), $36-50 \%$ as grade 7 (susceptible), $51-75 \%$ as grade 8 (highly susceptible), and $76-100 \%$ as grade 9 (highly susceptible).

\section{RESULTS}

From a total of $79 \mathrm{BC}_{1}$ and $\mathrm{BC}_{2}$ lines of $E$. arundinaceus, resistance to smut ranging from grade 1 (highly resistant ) to grade 4 (moderately resistant) was detected in $12.7 \%$ ( 10 out of 79 ) lines (Table 1$)$. The percentage of resistant lines in $\mathrm{BC}_{1}$ of $E$. arundinaceus $(18.9 \%$, seven out of 37$)$ was higher than that of $\mathrm{BC}_{2}(7.1 \%$, three out of 42). In $\mathrm{BC}_{1}$ of E. arundinaceus, five (13.5\%) of the 37 tested $\mathrm{BC}_{1}$ lines were highly resistant to smut. Resistant was found in 5.4\% (two out of 37) of $\mathrm{BC}_{1}$ lines, and $81.1 \%$ (30 out of 37 ) of $\mathrm{BC}_{1}$ lines were susceptible to smut, ranging from grade 5 (moderately susceptible) to grade 9 (highly susceptible). Of the $\mathrm{BC}_{2}$ lines of E. arundinaceus, one line was scored as highly resistant (grade 1), counting for $2.4 \%$ ( 1 out of 42 ), two lines exhibited resistance (grade 3 ) to smut, and $92.9 \%$ (39 out of 42 ) lines were susceptible to smut, ranging from grade 5 (moderately susceptible) to grade 9 (highly susceptible). The female parent YC96-40 ( $\mathrm{F}_{1}$ of $E$. arundinaceus) and the male parent CP84-1198 (commercial sugarcane cultivar) of $\mathrm{BC}_{1}$ were both susceptible to smut, while the female parent YCE 01-116 ( $\mathrm{BC}_{1}$ of E. arundinaceus) and male parent Neijiang57-416 (commercial sugarcane cultivar) of $\mathrm{BC}_{2}$ were both highly susceptible to smut.

\section{DISCUSSION}

In modern sugarcane breeding, the screening, identification and evaluation of systemic resistance in source materials is critical due to the importance of wild sugarcane resources as a source of resistance genes. Subsequent characterization and utilization of wild resistance genes can be used to broaden the genetic base of sugarcane resistance against disease and has important significance for screening and breeding of resistant cultivars ( $\mathrm{Li}$ et al., 2013). Sugarcane smut has been the major sugarcane disease in mainland China in recent years. In this study, a total of 79 backcross progenies $\left(\mathrm{BC}_{1}\right.$ and $\left.\mathrm{BC}_{2}\right)$ of $E$. arundinaceus were screened for resistance to smut using artificial inoculation method. Seven $\mathrm{BC}_{1}$ and three $\mathrm{BC}_{2}$ lines of $E$. arundinaceus were identified as highly to moderately resistant germplasms, which could provide an elite array of resistance sources for effective breeding of sugarcane cultivars against smut. 
W.K. Shen et al.

TABLE 1 - Identification of smut resistance in $\mathrm{BC}_{1}$ and $\mathrm{BC}_{2}$ lines from the crossing Erianthus arundinaceus $\times$ Saccharum by artificial inoculation.

\begin{tabular}{|c|c|c|c|c|c|}
\hline Line & Type & $\begin{array}{l}\text { Latent period } \\
\text { (days) }^{1}\end{array}$ & Incidence (\%) & Grade & Resistance response $^{2}$ \\
\hline 78 & $\mathrm{BC}_{2}$ & 174 & 13 & 5 & MS \\
\hline 373 & $\mathrm{BC}_{2}$ & 81 & 100 & 9 & HS \\
\hline 135 & $\mathrm{BC}_{2}$ & 81 & 62 & 8 & HS \\
\hline 393 & $\mathrm{BC}_{2}$ & 65 & 43 & 7 & $\mathrm{~S}$ \\
\hline 163 & $\mathrm{BC}_{2}$ & 124 & 29 & 6 & $\mathrm{~S}$ \\
\hline 221 & $\mathrm{BC}_{2}$ & 174 & 14 & 5 & MS \\
\hline 325 & $\mathrm{BC}_{2}$ & 65 & 63 & 8 & HS \\
\hline 226 & $\mathrm{BC}_{2}$ & 124 & 23 & 5 & MS \\
\hline 69 & $\mathrm{BC}_{2}$ & 124 & 36 & 7 & S \\
\hline 75 & $\mathrm{BC}_{2}$ & 81 & 79 & 9 & HS \\
\hline 323 & $\mathrm{BC}_{2}$ & 65 & 62 & 8 & HS \\
\hline 79 & $\mathrm{BC}_{2}$ & 109 & 85 & 9 & HS \\
\hline 385 & $\mathrm{BC}_{2}$ & 81 & 62 & 8 & HS \\
\hline 116 & $\mathrm{BC}_{2}$ & 81 & 87 & 9 & HS \\
\hline 37 & $\mathrm{BC}_{2}$ & 81 & 47 & 7 & S \\
\hline 250 & $\mathrm{BC}_{2}$ & 174 & 8 & 3 & $\mathrm{R}$ \\
\hline 327 & $\mathrm{BC}_{2}$ & 81 & 55 & 8 & HS \\
\hline 218 & $\mathrm{BC}_{2}$ & 81 & 47 & 7 & $\mathrm{~S}$ \\
\hline 356 & $\mathrm{BC}_{2}$ & 65 & 92 & 9 & HS \\
\hline 277 & $\mathrm{BC}_{2}$ & 81 & 42 & 7 & $\mathrm{~S}$ \\
\hline 105 & $\mathrm{BC}_{2}$ & 81 & 43 & 7 & $\mathrm{~S}$ \\
\hline 349 & $\mathrm{BC}_{2}$ & 81 & 46 & 7 & $\mathrm{~S}$ \\
\hline 333 & $\mathrm{BC}_{2}$ & 81 & 39 & 7 & $\mathrm{~S}$ \\
\hline 41 & $\mathrm{BC}_{2}$ & n.a. & 0 & 1 & HR \\
\hline 138 & $\mathrm{BC}_{2}$ & 65 & 50 & 7 & $\mathrm{~S}$ \\
\hline 94 & $\mathrm{BC}_{2}$ & 124 & 8 & 3 & $\mathrm{R}$ \\
\hline 220 & $\mathrm{BC}_{2}$ & 65 & 80 & 9 & HS \\
\hline 20 & $\mathrm{BC}_{2}$ & 81 & 58 & 8 & HS \\
\hline 16 & $\mathrm{BC}_{2}$ & 81 & 100 & 9 & HS \\
\hline 381 & $\mathrm{BC}_{2}$ & 81 & 75 & 8 & HS \\
\hline 300 & $\mathrm{BC}_{2}$ & 81 & 67 & 8 & HS \\
\hline 150 & $\mathrm{BC}_{2}$ & 65 & 83 & 9 & HS \\
\hline 279 & $\mathrm{BC}_{2}$ & 124 & 23 & 5 & MS \\
\hline 231 & $\mathrm{BC}_{2}$ & 81 & 31 & 6 & $\mathrm{~S}$ \\
\hline 313 & $\mathrm{BC}_{2}$ & 124 & 21 & 5 & MS \\
\hline 104 & $\mathrm{BC}_{2}$ & 109 & 60 & 8 & HS \\
\hline
\end{tabular}


Evaluation of $\mathrm{BC} 1$ and $\mathrm{BC} 2$ from the crossing Erianthus arundinaceus with Saccharum for resistance...

\begin{tabular}{|c|c|c|c|c|c|}
\hline Line & Type & $\begin{array}{l}\text { Latent period } \\
\quad(\text { days })^{1}\end{array}$ & Incidence $(\%)$ & Grade & Resistance response $^{2}$ \\
\hline 53 & $\mathrm{BC}_{2}$ & 174 & 20 & 5 & MS \\
\hline 11 & $\mathrm{BC}_{2}$ & 81 & 38 & 7 & $\mathrm{~S}$ \\
\hline 53 & $\mathrm{BC}_{2}$ & 174 & 20 & 5 & MS \\
\hline 11 & $\mathrm{BC}_{2}$ & 81 & 38 & 7 & S \\
\hline 14 & $\mathrm{BC}_{2}$ & 174 & 29 & 6 & $\mathrm{~S}$ \\
\hline 145 & $\mathrm{BC}_{2}$ & 81 & 23 & 5 & MS \\
\hline 265 & $\mathrm{BC}_{1}$ & n.a. & 0 & 1 & HR \\
\hline 46 & $\mathrm{BC}_{1}$ & 81 & 43 & 7 & $\mathrm{~S}$ \\
\hline 49 & $\mathrm{BC}_{1}$ & n.a. & 0 & 1 & $\mathrm{HR}$ \\
\hline 15 & $\mathrm{BC}_{1}$ & 65 & 42 & 7 & $\mathrm{~S}$ \\
\hline 30 & $\mathrm{BC}_{1}$ & 81 & 67 & 8 & HS \\
\hline 28 & $\mathrm{BC}_{1}$ & 65 & 89 & 9 & HS \\
\hline 372 & $\mathrm{BC}_{1}$ & 65 & 64 & 8 & HS \\
\hline 9 & $\mathrm{BC}_{1}$ & 81 & 40 & 7 & $\mathrm{~S}$ \\
\hline 25 & $\mathrm{BC}_{1}$ & 81 & 44 & 7 & $\mathrm{~S}$ \\
\hline 151 & $\mathrm{BC}_{1}$ & 174 & 50 & 7 & $\mathrm{~S}$ \\
\hline 204 & $\mathrm{BC}_{1}$ & 65 & 70 & 8 & HS \\
\hline 366 & $\mathrm{BC}_{1}$ & 81 & 40 & 7 & $\mathrm{~S}$ \\
\hline 4 & $\mathrm{BC}_{1}$ & 81 & 56 & 8 & HS \\
\hline 1 & $\mathrm{BC}_{1}$ & 81 & 50 & 7 & $\mathrm{~S}$ \\
\hline 121 & $\mathrm{BC}_{1}$ & 124 & 29 & 6 & $\mathrm{~S}$ \\
\hline 240 & $\mathrm{BC}_{1}$ & 124 & 71 & 8 & HS \\
\hline 182 & $\mathrm{BC}_{1}$ & n.a. & 0 & 1 & HR \\
\hline 64 & $\mathrm{BC}_{1}$ & 65 & 69 & 8 & HS \\
\hline 126 & $\mathrm{BC}_{1}$ & 81 & 60 & 8 & HS \\
\hline 189 & $\mathrm{BC}_{1}$ & 65 & 82 & 9 & HS \\
\hline 56 & $\mathrm{BC}_{1}$ & 81 & 50 & 7 & $\mathrm{~S}$ \\
\hline 358 & $\mathrm{BC}_{1}$ & 174 & 9 & 3 & $\mathrm{R}$ \\
\hline 282 & $\mathrm{BC}_{1}$ & 109 & 20 & 5 & MS \\
\hline 396 & $\mathrm{BC}_{1}$ & 65 & 100 & 9 & HS \\
\hline 352 & $\mathrm{BC}_{1}$ & 174 & 9 & 3 & $\mathrm{R}$ \\
\hline 390 & $\mathrm{BC}_{1}$ & 81 & 43 & 7 & $\mathrm{~S}$ \\
\hline 24 & $\mathrm{BC}_{1}$ & 174 & 15 & 5 & MS \\
\hline 302 & $\mathrm{BC}_{1}$ & 81 & 40 & 7 & $\mathrm{~S}$ \\
\hline 179 & $\mathrm{BC}_{1}$ & 81 & 27 & 6 & $\mathrm{~S}$ \\
\hline 374 & $\mathrm{BC}_{1}$ & 50 & 91 & 9 & HS \\
\hline 22 & $\mathrm{BC}_{1}$ & 81 & 57 & 8 & HS \\
\hline
\end{tabular}




\begin{tabular}{|c|c|c|c|c|c|}
\hline Line & Type & $\begin{array}{l}\text { Latent period } \\
\quad(\text { days })^{1}\end{array}$ & Incidence (\%) & Grade & Resistance response $^{2}$ \\
\hline 154 & $\mathrm{BC}_{1}$ & 124 & 33 & 6 & $\mathrm{~S}$ \\
\hline 74 & $\mathrm{BC}_{1}$ & 81 & 63 & 8 & HS \\
\hline 6 & $\mathrm{BC}_{1}$ & n.a. & 0 & 1 & HR \\
\hline 296 & $\mathrm{BC}_{1}$ & 81 & 50 & 7 & $\mathrm{~S}$ \\
\hline 158 & $\mathrm{BC}_{1}$ & n.a. & 0 & 1 & HR \\
\hline 100 & $\mathrm{BC}_{1}$ & 81 & 50 & 7 & $\mathrm{~S}$ \\
\hline \multicolumn{2}{|c|}{ CP84-1198 (Male parent, cultivar) } & 124 & 30 & 6 & S \\
\hline \multicolumn{2}{|c|}{ YC96-40 (Female parent, $\left.F_{1}\right)$} & 109 & 28 & 6 & $\mathrm{~S}$ \\
\hline \multicolumn{2}{|c|}{ YCE01-116 (Female parent, $\mathrm{BC}_{1}$ ) } & 124 & 57 & 8 & HS \\
\hline \multicolumn{2}{|c|}{ Neijiang57-416 (Male parent, cultivar) } & 65 & 54 & 8 & HS \\
\hline
\end{tabular}

${ }^{1}$ n.a., not applicable.

${ }^{2}$ Resistance response: HR, highly resistant; R, resistant; MR, moderately resistant; MS, moderately susceptible; S, susceptible; HS, highly susceptible.

In this study, backcross progenies of E. arundinaceus with Saccharum showed no stronger resistance ability to smut, leading to only $18.9 \%$ of $\mathrm{BC}_{1}$ lines and $7.1 \%$ of $\mathrm{BC}_{2}$ lines with highly to moderate resistance. The main reason was that the backcross progenies derived from susceptible crossings: $\mathrm{BC}_{1}$ lines from a susceptible vs. susceptible crossing, and $\mathrm{BC}_{2}$ lines from a highly susceptible vs. highly susceptible crossing. The heritability of sugarcane smut resistance is moderate (Wu et al., 1977, 1983; Comstock, 1983; Chao et al., 1990) therefore the resistance level of parental combinations affected the resistance ability of the offspring. On the other hand, $\mathrm{BC}_{1}$ and $\mathrm{BC}_{2}$ plants of $E$. arundinaceus have larger buds with smaller or no sprout wings, which are morphological features that may be beneficial to germination and infection of $S$. scitamineum (Muthusamay, 1974; Padmanaban et al., 1988a, 1988b) and thus may also have affected the resistance backcross progenies of $E$. arundinaceus to smut. Piperidis et al. (2010) reported that in the $\mathrm{BC}_{1}$ lines of E. arundinaceus the number of chromosomes ranged from 21 to 30 , while in the $\mathrm{BC}_{2}$ lines the number ranged from 14 to 15 , revealing cases of chromosome loss. Therefore, it is possible that resistance genes were lost in backcross progenies of $E$. arundinaceus, which may have lead to hybrid offspring without stronger resistance against smut.

In the future, further studies are needed to objectively evaluate the resistance ability of backcross progenies of $E$. arundinaceus to smut from resistant vs. resistant crossings or highly resistant vs. highly resistant crossings. It would be useful to get more promising resistance sources against sugarcane smut disease and reveal prospect of $E$. arundinaceus in breeding for resistance to smut.

In conclusion, this study has identified ten $\mathrm{BC}_{1}$ and $\mathrm{BC}_{2}$ lines of $E$. arundinaceus with resistance against sugarcane smut disease out of 79 tested lines, broadening the genetic basis of smut resistance in sugarcane breeding.

\section{ACKNOWLEDGEMENTS}

This work was supported by grants from the Earmarked Fund for Key Agriculture Project of Guangdong Province, China (2010B020302001) and the Earmarked Fund for President Project of South China Agricultural University, China (K13009).

\section{REFERENCES}

Antoine R (1961) Smut. In: Martin JP, Abbott EV, Hughes CG (Eds.) Sugarcane Diseases of the World. Amsterdam, The Netherlands. Elsevier. pp. 327-354.

Berding N, Roach BT (1987) Germplasm collection, maintenance, and use. In: Heinz DJ (Ed.) Sugarcane Improvement Through Breeding. Amsterdam, The Netherlands. Elsevier. pp. 143-210.

Bhuiyan SA, Croft BJ, James RS, Cox MC (2012) Laboratory and field evaluation of fungicides for the management of sugarcane smut caused by Sporisorium scitamineum in seedcane. Australasian Plant Pathology 41:591-599.

Chao CP, Hoy JW, Martin FA (1990) Heritability of resistance and repeatability of clone reactions to sugarcane smut in Louisiana. Phytopathology 80:622-626.

Chen RK,Yuan ZN (2010) Sugarcane production and research in China. International Sugar Journal 112:452-457.

Chen YS, Deng HH, Liang JN, Li QW, Tan ZW (2006) Differences of physiological and biochemical characters among the progenies of Erianthus arundinaceus. Journal of Huazhong Agricultural University 25:598-602.

Comstock JC (2000) Smut. In: Rott P, Bailey RA, Comstock JC, 
Croft BJ, Saumtally AS (Eds.) A guide to sugarcane diseases. Montpellier, France. CIRAD and ISSCT. pp. 181-185.

Comstock K JC, Ferreira SA, Tew TL (1983) Hawaii’s approach to control sugarcane smut. Plant Disease 67:452-457.

Deng HH, Fu C, Chen B, Yu ZL, Tan ZW, Li QW, Chen PS, Liang JN (2007) Differences of physiological and biochemical characters of leaves between BC2 lines of Erianthus arundinaceus and their parents. Journal of Huazhong Agricultural University 26:766771.

Deng HH, Hu C, Li QW, Liao ZZ, Chen XW, Liang JN, Zhang CM, Tan ZW (2004) Studies on fertile $S$. officinarum $\times$ E. arundinaceus hybrids and their BC1 performance. Chinese Journal of Tropical Crops 25:97-101.

Deng ZH, Zhang MQ, Lin WL, Fu C, Zhang CM, Li YC, Lai LP, Lin YQ, Chen RK (2010) Analysis of disequilibrium hybridization in hybrid and backcross progenies of Saccharum officinarum $\times$ Erianthus arundinaceus. Agricultural Sciences in China 9:1271-1277.

Fukuhara S, Terajima Y, Irei S, Sakaigaichi T, Ujihara K, Sugimoto A, Matsuoka M (2013) Identification and characterization of intergeneric hybrid of commercial sugarcane (Saccharum spp. hybrid) and Erianthus arundinaceus (Retz.) Jeswiet. Euphytica 189:321-327.

George P, Mandy J, Christopher B, Carroll J, Berding N, D'Hont A (2000) Molecular contribution to selection of intergeneric hybrids between sugarcane and the wild species Erianthus arundinaceus. Genome 43:1033-1037.

He HY, Lao FY, Liu R, Chen JW (2008) Molecular marker analysis of the progenies derived from intergeneric cross of Saccharum with Erianthus arundinaceus. Journal of Huazhong Agricultural University 27:573-577.

Li WF, Wang XY, Huang YK, Shan HL, Luo ZM, Ying XM, Zhang RY, Shen K, Yin J (2013) Screening sugarcane germplasm resistant to Sorghum mosaic virus. Crop Protection 43:27-30.

McMartin A (1945) Sugarcane smut: Reappearance in Natal. South African Journal of Sugar 29:55-57.

Muthusamay S (1974) Varietal susceptibility to smut in relation to bud characters. Proceedings of the International Society of Sugar Cane Technologists 22:737-749.
Padmanaban P, Alexander KC, Shanmugan N (1988a) Mechanism of smut resistance in sugarcane. Sugar Cane 6:14-16.

Padmanaban P, Alexander KC, Shanmugan N (1988b) Studies on certain characters associated with smut resistance in sugarcane. Indian Phytopathology 41:594-598.

Piperidis N, Chen JW, Deng HH, Wang LP, Jackson P, Piperidis G (2010) GISH characteriztion of Erianthus arundinaceus chromosomes in three generations of sugarcane intergeneric hybrids. Genome 53:331-336.

Presley J (1978) The culmicolous smut of sugarcane. Sugar 73:3439.

Que YX, Xu LP, Lin JW, Chen RK, Grisham MP (2012) Molecular variation of Sporisorium scitamineum in Mainland China revealed by RAPD and SRAP markers. Plant Disease 96:1519-1525.

Shen WK (2002) Discussion of the value of intergeneric crosses of Saccharum $\times$ Erianthus. Sugar Cane 9:1-5.

Shen WK, Deng HH (2011) Analysis of results from smut resistant identification in sugarcane varieties introduced. Chinese Agricultural Sciences Bulletin 27:234-238.

Shen WK, Jiang ZD, Deng HH, Liu R (2013) Research progress on sugarcane smut disease and Sporisorium scitaminea. Chinese Journal of Tropical Crops 34:2063-2068.

Shen WK, Jiang ZD, Yang ZD, Liu R, Chen JW, Deng HH (2014) New resistance identification method and resistance evaluation of sugarcane varieties to smut disease. Journal of Huazhong Agricultural University 33:51-56.

Stoll M, Piepenbring M, Begerow D, Oberwinkler F (2003) Molecular phylogeny of Ustilago and Sporisorium species (Basidiomycota, Ustilaginales) based on internal transcribed spacer (ITS) sequences. Canadian Journal of Botany 81:976-984.

Wada AC (2003) Control of sugarcane smut disease in Nigeria with fungicides. Crop Protection 22:45-49.

Wu KK, Heinz DJ, Meyer HK (1983) Heritability of sugarcane smut resistance and correlation between smut grade and yield compoments. Crop Science 43:54-56.

Wu KK, Ladd SL, Meyer HK (1977) Combining ability analysis in sugarcane smut resistance. Sugarcane Breed Newsletter 39:5962.

TPP-2014-0011

Submitted: 25 January 2014

Revisions requested: 17 March 2014 Accepted: 19 May 2014

Section Editor: Rosana Rodrigues 